UDC 658.330

\title{
Innovative development of industrial enterprises on the basis of adaptive process
}

\author{
Mehovich S.A. \\ Doctor of Economics, \\ Professor of the Department of Economic Analysis and Accounting, \\ National Technical University "Kharkov Polytechnic Institute" \\ Siketina N.H. \\ Assistant Professor of the Department of Economic Analysis and Accounting, \\ National Technical University "Kharkov Polytechnic Institute"
}

\begin{abstract}
The article is devoted to topical issues of adaptation of industrial enterprises under the influence of a changing competitive environment. The theoretical issues of the economic category of "adaptation", "adaptation process" and "adaptation system" with respect to industrial enterprises are investigated. The basis for ensuring the development of industrial enterprises has been determined. The system nature of the task of optimizing the interaction of the external and internal structure of the enterprise has been determined.
\end{abstract}

Keywords: adaptation, adaptation process, enterprise adaptation management, strategy.

Мехович С.А., СікєТіна Н.Г. АДАПТАЦІЙНИЙ ПРОЦЕС В ІННОВАЦІЙНОМУ РОЗВИТКУ ПРОМИСЛОВИХ ПІДПРИЕМСТВ

Стаття присвячена актуальним питанням адаптації промислових підприємств під впливом мінливого конкурентного середовища. Досліджено теоретичні питання економічної категорії «адаптація», «адаптаційний процес» та «адаптаційна система» відносно промислових підприємств. Визначено основу забезпечення розвитку промислових підприємств. Окреслено системний характер завдання оптимізації взаємодії зовнішньої й внутрішньої структури підприємства.

Ключові слова: адаптація, адаптаційний процес, адаптаційне управління, підприємство, стратегія.

МеХОвИч С.А., СИКеТИНа Н.Г. АДАПТАЦИОННЫЙ ПРОЦЕСС В ИННОВАЦИОННОМ РАЗВИТИИ ПРОМЫШЛЕННЫХ ПРЕДПРИЯТИЙ

Статья посвящена актуальным вопросам адаптации промышленных предприятий под влиянием меняющейся конкурентной среды. Исследованы теоретические вопросы экономической категории «адаптация», «адаптационный процесс» и «адаптационная система» относительно промышленных предприятий. Определены основу обеспечения развития промышленных предприятий. Определены системный характер задачи оптимизации взаимодействия внешней и внутренней структуры предприятия.

Ключевые слова: адаптация, адаптационный процесс, адаптационное управления, предприятие, стратегия.

Introduction. The strategy of Ukraine's integration into the European Union defined the course on the development of the national economy by an innovative model [1]. This put ambitious tasks for enterprises not only to maintain the current state of development, but to enter the world level of competitiveness.

It should be noted that in a crisis market environment, dominant market strategies are strategies for survival and simple reproduction, while the development strategy, which involves a higher level of entrepreneurial activity, ceases to be among the main strategies for adaptation.

So during the exacerbation of the economic crisis, almost all domestic enterprises, especially small and medium-sized businesses, which choose a development strategy and are oriented towards the introduction of innovative technologies, re-engineering business and retraining of personnel, do not have sufficient financial resources for this, and obtaining credit resources is practically unrealistic.

Therefore, an important consideration for correcting the economic situation in Ukraine should be the theory of a well-balanced, substantiated system of adaptation of domestic enterprises to conditions of a changing competitive environment.

Literature Survey. The problem of ensuring the development of industrial enterprises is considered in the works of domestic and foreign scientists, in particular, I. Ansoff, O. Vikhran- 
sky, G. Geyer, A. Gutman, J. Dunning, V. Dikan, P. Drucker, A. Zagorodniy, S. Kummingas, Yu. Kindzersky, S. Klymenko, O. Kokun, N. Kondratiev, M. Meskon, G. Mintzberg, E. Mozharov, V. Nemtsov, V. Pavlova, M. Porter, L. Poddubnaya, S. Pokroplyvnogo, V Semynozhenko, R. Fatkutdinova, O. Chernegi, Z. Shershnyova, V. Shynkarenko, V. Yakimkin and others.

Simultaneously, the analysis of scientific works in the field of adaptation theory and adaptation management shows the lack of a clear methodology of the system of adaptation of domestic enterprises to a changing competitive environment and points to the need for further in-depth study of the managerial aspects of ensuring the system of adaptation of industrial enterprises in the domestic and foreign markets.

Problem statement. The issue of adaptation of industrial enterprises taking into account the requirements of the environment is an extremely difficult task that cannot be uniquely solved due to the specific conditions in which the enterprises are located and their financial and economic status. The need for a comprehensive solution to this issue makes it relevant to conduct research aimed at developing theoretical positions and practical solutions for the adaptation process and the effective management of the system of adaptation in the current market conditions.

Formulating the goals of the article (statement of the task). The main objective of the article is to study and generalize theoretical and methodological aspects of the theory of adaptation and adaptation process of domestic enterprises for their further development.

Results. The specific socio-economic reality of domestic industrial enterprises is variable, diverse and complex. These properties of economic reality are the main causes of the difficulties of its scientific knowledge. But, as stated by N.D. Kondratiev, "the scientific knowledge of this reality is still possible and reveals certain successes only because science decomposes simple and homogeneous elements and only then makes their synthesis" [2, p. 9].

The extremely changing nature of the market environment distorts market conditions, when traditional methods of conducting economic activity no longer guarantee the maintenance of the acquired market positions. New approaches to defining development strategies from the mission are needed, and the search for mechanisms for adapting to emerging changes. Here it should be remembered warning to Michael Porter that "the constant flexibility of the strategy transforms the competitive advantage into practical inac- cessibility. By changing one strategy to another, it is impossible to succeed in any of them. Permanent new idea's developments are important for maintaining productive efficiency, but this may not correspond to a sustainable strategic position" [3, p. 18]. If in the absence of a strategy to the goal can lead a lot of ways, then a certain strategy allows you to choose only the optimal.

Note that the concept of optimality itself is ambiguous - it is necessary for the enterprise being investigated, the fastest way, or the shortest, or the nicest. Figuratively speaking, the system of adaptation and strategy is similar to the forces of "yin" and "Yang" of ancient Chinese philosophy, which characterize the balance of preservation and change. Everything is well in this world based on the interaction of these forces that complement each other.

Solving the problem of optimizing the interaction of the external and internal structure of the enterprise is systemic. It is from the balance of the interaction of an industrial enterprise with a changing external environment that depends on its adaptive process in innovative development.

The adaptation process provides a certain level of stability, the ability to maintain a high degree of compliance with applicable technology and business needs management. At the same time, the strategy defines the necessary process of managed, purposeful change and progress in technologies that are necessary to meet the future needs of the organization.

In particular, the system's development strategy defines promising directions, so that the choice of each individual solution depends on specific tasks, taking into account the general predetermined direction. Implementation of individual requirements is possible by choosing a specific solution and in the absence of a strategy, but a set of such solutions will be extremely ineffective in terms of the prospects of the development of the entire enterprise as a whole. Projects will be poorly linked to each other, budgets and terms will be more likely to be exceeded, and business units will be dissatisfied with how the management and enterprise operate.

One of the principles of system thinking asserts: what is as good for each part is usually the best for the whole system as a whole. If the interests of one part (for example, owners) are maximized, then this inevitably means certain losses for other parts.

Therefore, of course, a "positive" strategy is the product of a compromise between business and owners, as well as between the various technologies used in the enterprise. 
The modern term "adaptation" comes from the Latin adaptation - "adaptation", which means that in ancient time's adaptation was seen as a process of adapting any system to real-life conditions. In later times in the writings of researchers who represented various scientific directions, various interpretations and interpretations of the concept of "adaptation" were proposed. Adaptation was considered in scientific works and as a principle that determines the content and specifics of management activity, and as a phenomenon or procedure with certain conditions, and as an action or set of procedures with certain results, and as a certain process or a complex task, the implementation of which contributes to the solution of a particular problem [4-9].

The treatment of adaptation as a process is characterized by the complexity caused by many alternatives to strategies of adaptive behavior, the existence of many examples of adaptation of the subject to the environment. Initially, the adaptation was considered in relation to technical objects within the framework of the creation of automatic control systems for these objects. In the future, the concept of "adaptation" has become a general scientific category. The content of this term began to bind with the characteristic of the adaptive reactions of the human body to changes in the environment.

In terms of R. Acoff, adaptation is a response to a change that can actually or potentially reduce the efficiency of the operation of a particular system, or a system response that impedes its weakening [10]. This change can be either internal, that is, carried out within the system itself, or external - within the framework of the environment. According to R. Acoff, adaptive responses are of two types. The first of these is associated with passive adaptation, which involves changing the system of its behavior in order to increase the efficiency of functioning in a constantly changing external environment. The second kind of adaptive reviews involves active adaptation, which includes the impact of the system on the external environment, which aims to make systemic behavior more effective in the present and in the future.

Changes in the external environment can be fast and short, slow and slow, and the adaptive system should ideally deal with both situations, adapting to the circumstances. Within this approach, adaptation in the broad sense should be defined as the ability of the system to adapt to changing environmental conditions, various negative changes that originate from the external environment and have an appropriate influence on the functioning of this system (Fig. 1).

Consequently, two main groups of objectives of the adaptation process of the enterprise are distinguished: those which are related to bringing the internal environment into conformity with the factors of the environment, and those which are related to the ability of the organization to somehow resist external factors and even influence them in case further changes.

Since the state of relative stability and the sustainable functioning of the external market environment, as a rule, are short-lived under the influence of various objective factors, it is logical to respond in an optimal adaptive strategy to adapt to factors. This approach is conditioned by the needs of enterprises to be prepared for external influences.

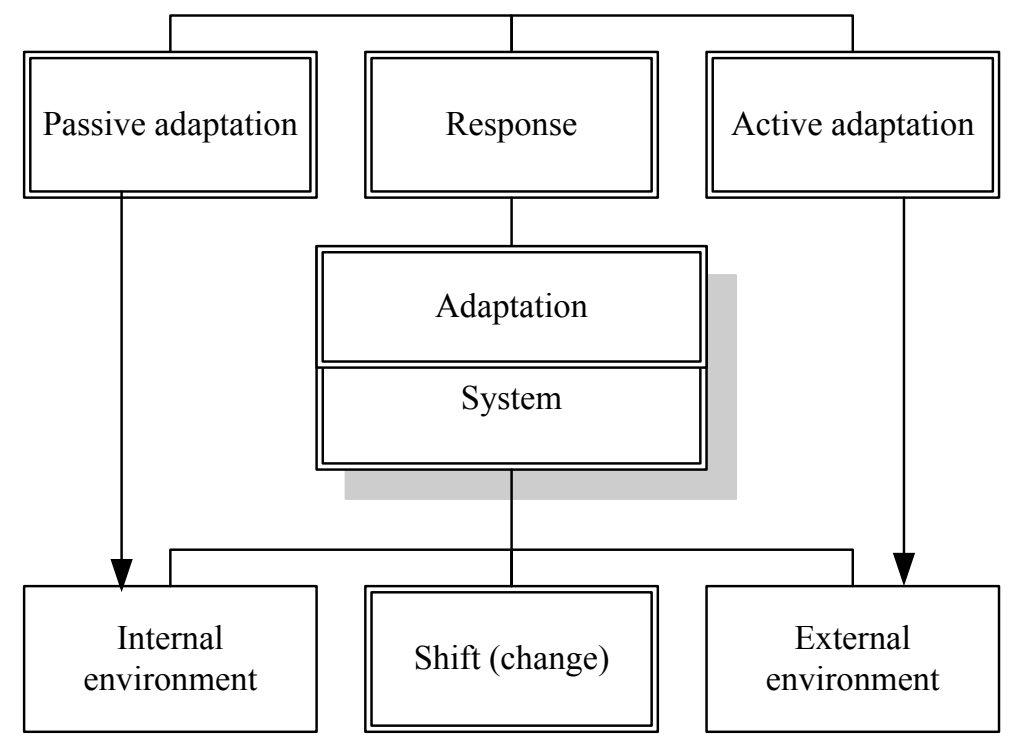

Fig. 1. The structure of the concept of "adaptation" 
Accordingly, it is appropriate to consider adaptation within the framework of this study as a process of ensuring the stability of a market entity to changes occurring in the external or internal environment of its functioning, which is provided on the basis of various adaptation strategies.

The changes discussed do not necessarily have to be related to the phenomena of a crisis nature, although the crisis situation involves the development of the most optimal adaptation strategies. In the case of adaptation, the language may refer to changes in the direction that the subject may face and who require an adequate response. Consequently, the process of adapting to changes is called the adaptation process that can be defined as a consistent change in the position of the enterprise in time, while providing at the same time its individuality, optimal compliance with the requirements of the environment and its own strategic ambitions.

The adaptation process is dynamic and is in development, because the functional capabilities of leading and secondary subsystems and parts of the enterprise all the time change due to the instability of the environment that determines them (production capacity, production volume, aggregate needs, sales, etc.). Adaptation process is a business process (business process) that is, an activity that has an input product adds value to it, and provides a source product for an internal or external consumer.

Due to different abilities and level of development, different subjects differ in their ability to adapt. There are four types of adaptive mechanisms characterized by fundamental differences from each other [11]. The first of them involves adaptation as development, the second adaptation as protection, the third - as care or evasion, and the fourth - as a reversal. If the first model can be regarded as uniquely positive, since it involves improving the internal structure of the subject of adaptation, then the latter, by contrast, is negative, both in its orientation and in its content. With regard to the second and third models of adaptation, they can be both neutral and negative, depending on the context of the event. Various models assume different adapta- tion strategies, the choice of which determines the specific focus of the subject's behavior.

Practically there is an intermediate version of the strategy, which involves the desire of the subject to "wait for the adaptive situation, to see what will happen next", without any radical measures or limited to a temporary adjustment option. An optimal decision to apply these or other strategies can be made on the basis of factor analysis.

Conclusions from this study. The theory of a reasonable system of adaptation to the conditions of a changing competitive environment of domestic enterprises is a guarantee of their sustainable development and of the whole country. The task of optimizing the interaction of the external and internal structure of the enterprise is systemic. Indeed, from the balance of interaction of an industrial enterprise with a changing environment, its adaptation process in innovative development depends on it.

Consequently, adaptation within the framework of this study should be considered as a process of ensuring the stability of a market entity to changes that arise in the external or internal environment of its functioning, which is provided on the basis of various adaptation strategies.

The main components of the adaptation process are considered in order to determine its specificity for the Ukrainian industry. In general, the process of adaptation of an enterprise to changes in the environment can be presented in the development and implementation of a system of adaptation of enterprises, which is based on the production of competitive products.

Provision of the industrial enterprise adaptation system is based on a comprehensive analysis of the internal and external environment.

For the study of the internal environment, methods of financial-economic, technological, portfolio analysis, as well as analysis of organizational structure and marketing strategy is used.

The study of the environment is aimed at the analysis of the market of sales, consumers, competitors, analysis of the state economic policy and study of the specifics of the industry.

\section{REFERENCES:}

1. "Stratehiia intehratsii Ukrainy do Yevropeiskoho Soiuzu" ["Strategy of Ukraine's integration into the European Union"]. Available at: http://zakon1.rada.gov.ua/laws/show/615/98 (accessed (30/10/2018)).

2. Kondratiev N.D. (2002) Bolshye tsyklb koniunktury y teoryy predvydenyia. Yzbrannye trudy [Big cycles of conjuncture and theory of foresight. Selected works]. Moscow: Publishing house "Economics". (in Russian)

3. Porter Michael (2007) Konkurentnaia stratehyia: metodyka analyza otraslei y konkurentov [Competitive strategy: a methodology for analyzing industries and competitors]. Moscow: Alpina Business Bus. (in Russian) 
4. Chyzhenkova E. V. (2006) Formyrovanye ekonomycheskoho mekhanyzma adaptatsyy khoziaistvuiushcheho subekta k rynochnoi srede [Development of an Economic Mechanism for the Adaptation of the Business Entity to the Market Environment] (PhD Thesis), Orel: Orlov State Institute of Economics and Trade.

5. Khomenko A. I. Orhanizatsiina adaptatsiia mashynobudivnykh pidpryiemstv v seredovyshchi nevyznachenosti [Organizational adaptation of machine-building enterprises in an environment of uncertainty] (PhD Thesis), Lviv: National university "Lvov POLYTECHNIKA".

6. Kudlaenko S. V. Ekonomichnyi mekhanizm adaptatsii pidpryiemstv do kryzovykh umov [The economic mechanism of adaptation of enterprises to crisis conditions] (PhD Thesis), Khmelnytskiy: KHMELNYTSKIY NATIONAL UNIVERSITY.

7. Petrovich Y. M. Osnovni aspekty adaptatsii mashynobudivnykh pidpryiemstv do zmin zovnishnoho seredovyshcha $v$ umovakh rynkovykh transformatsii [Basic aspects of adaptation of machine-building enterprises to changes in the environment in conditions of market transformations] Available at: http://www.vuzllib.su/articles (accessed (21/10/2018)).

8. Dubchak V. V. Teoretyko-metodolohycheskye aspektы formyrovanyia systemb adaptyvnoho upravlenyia prombshlennыmy predpryiatyiamy [Theoretical and methodological aspects of the formation of the system of adaptive control by industrial enterprises] (PhD Thesis), Rostov-on-Don: Rostov-on-Don State University.

9. Kravchenko S.A. (2008) Adaptatsyia ekonomycheskoho mekhanyzma funktsyonyrovanyia selskokhoziaistvennykh predpryiatyi k uslovyiam rynka [Adaptation of the economic mechanism of functioning of agricultural enterprises to the market conditions: Monograph]. -K: NSC IAE. (in Russian)

10. Acoff R. (2002) Akoff o menedzhmente [Acoff on management]. SPb:. Peter (in Russian)

11. Korel L.V. (2005) Sotsyolohyia adaptatsyi: Voprosy teoryy, metodolohyy y metodyky [Sociology of adaptations: Questions of theory, methodology and methods] Novosibirsk: Science. (in Russian) 